\title{
Investigating the Moderating Role of Enjoyment in the Relationship between Brand Image, Service Quality, and Convenience in Search and Purchase Behaviour in Multichannel Retailing
}

\author{
Hamideh Bagheri ${ }^{1} \&$ Meysam Hemmatishabani ${ }^{1}$ \\ ${ }^{1}$ Tasmanian School of Business and Economics, University of Tasmania, Australia \\ Correspondence: Hamideh Bagheri, Tasmanian School of Business and Economics, University of Tasmania, \\ Australia. E-mail: hamideh.bagheri@gmail.com
}

Received: September 24, 2016

Accepted: November 7, 2016

Online Published: December 20, 2016

doi:10.5539/ass.v13n1p53

URL: http://dx.doi.org/10.5539/ass.v13n1p53

\begin{abstract}
Multi-channel shopping is a purchasing pattern by which consumers use multiple channels, such as the Internet, catalogue, mobile, and brick-and-mortar stores, to make purchases. The aim of this research was to investigate the factors affecting search online and purchase offline. Data collection was conducted using an online survey administered to a consumer panel in the US. Retrospective sampling was adopted for the study and the sampling framework for the present research consisted of consumers who had recent shopping experience with the offline channel and search experience using the online channel of a retailer. The results illustrated that all research question are not significant and were not effective on search online and purchase offline; however, brand image on online and offline channel had a significant effect on attract consumers to search online and purchase offline. This study had that consumer perception and satisfaction with service, brand image, and convenience has positive and significant effects on future intentions to search online and purchase offline. This study showed the role of search online as a mediator in the relationship between brand image, service quality, and convenience with offline purchase.
\end{abstract}

Keyword: brand image, enjoyment, service quality, purchase behaviour, multichannel retailing

\section{Introduction}

With advances in the Internet and information technology, more and more MCS is performed through both Internet and physical stores. A majority of consumers (67 percent) still prefer to purchase in physical stores (Pauwels et al., 2011), while using the Internet for information search regarding product features and prices (Mendelsohn et al., 2006). The practice of searching for information online and then choosing to buy in a physical store denotes both an opportunity and a threat to retailers (McIver et al., 2009). This strategy of researching online and buying offline has been coined 'web-to-store' shopping or 'research' shopping (Verhoef, Neslin, \& Vroomen, 2007). What is lacking is an understanding of why people choose to buy in-store after online information search, and what factors motivate consumers to buy from one channel rather than another.

Despite the ongoing interest by scholars in multichannel shopping, there is a lack of knowledge on issues associated with search online - purchase in-store behaviour. Factors that influence consumers to buy online, such as website design and product category have received substantial attention in the online consumer behaviour literature (McIver et al., 2009). However, there is very little research examining the how brand image, service quality and convenience influence on online and offline channel usage. Specifically, limited research has investigates how brand image, service quality and convenience lead to search online purchase offline behavior. Furthermore, a key limitation of previous studies concerns their focus on the online or offline store as a single channel (Verhagen \& Van Dolen, 2009). Online or offline activities cannot be considered in isolation, because they take place within the broader context of marketing activities conducted simultaneously (Peterson, Balasubramanian, \& Bronnenberg, 1997; Karimi Takalo et al., 2013).

In picking up on the issues raised in the literature this study seeks to understand how consumers' enjoyment in the offline shopping influences the impact of perceived service quality, brand image, and shopping convenience on consumers' search using online channels and shopping behaviour in the offline channels. And also, this study investigates the role of search online as a mediate in the relationships between service quality, brand image, and 
convenience with offline purchase. Practitioners can use these relationships and apply them in multichannel to attract more consumers to purchase from both online and offline channel.

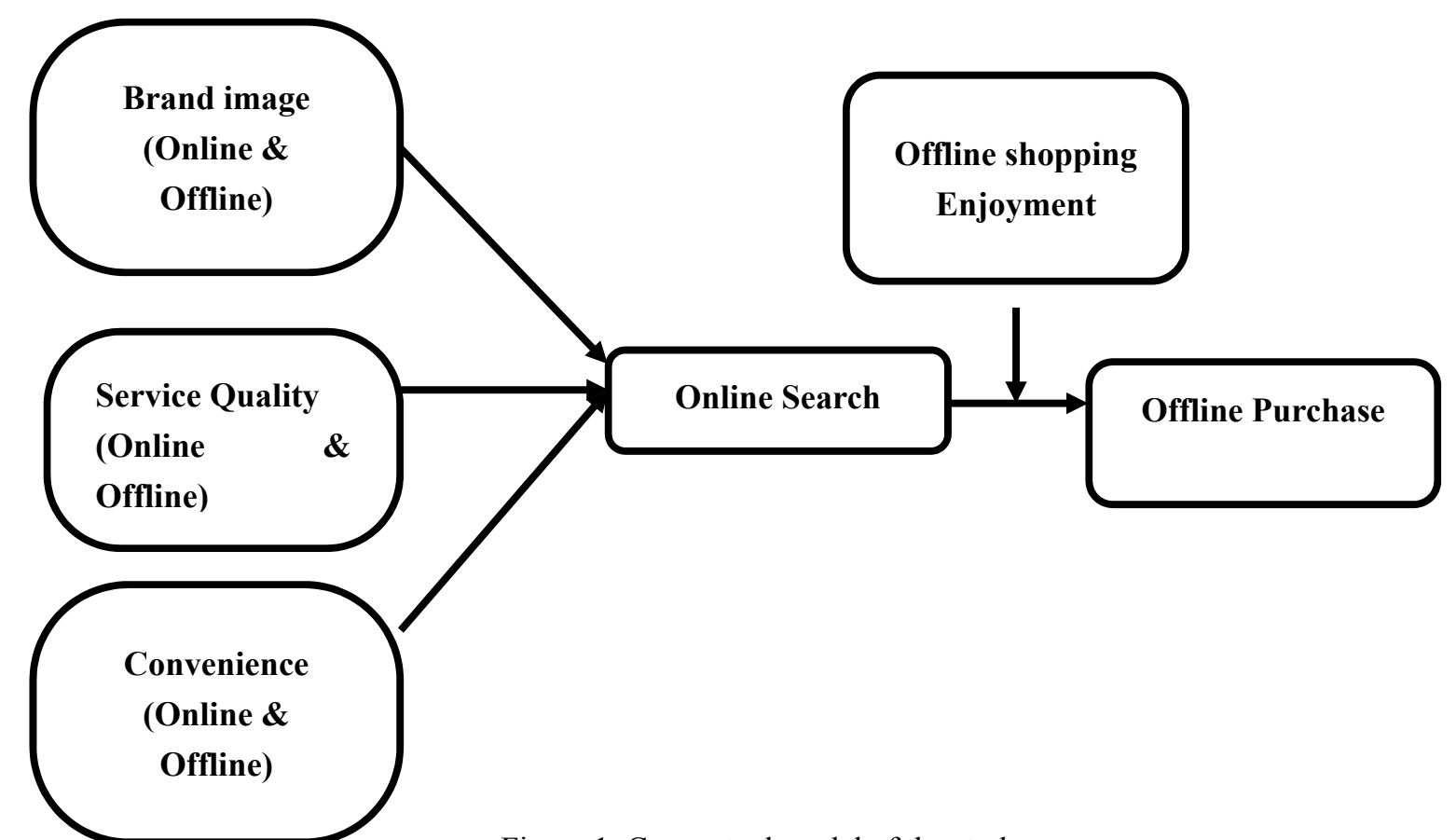

Figure 1. Conceptual model of the study

\section{Conceptual Framework and Research Questions}

The objective of this study is to understand why consumers search in online channel and purchase in offline channel and also retailers need to understand which channels consumers use to search or purchase.

\subsection{Multichannel Retailer Brand Image: Offline and Online}

Brands are an important tool for consumers to organise information and make their decision making simple in both online and traditional stores (Bergstrom, 2000). A brand's marketing activity is influenced by consumers according to the brand's image or associations with their past experiences with the brand (Brady et al., 2008; Keller, 1993).

Most brick-and-click retailers try to exploit the halo effect from their existing offline image by operating under the same retail brand name in both offline and online channels, even though their offline and online retail services may differ (Kwon \& Lennon, 2009).

According to (Lee et al., 2007) consumers' experiences with a firm in one channel may affect their perceptions and beliefs about the same firm in another channel. Therefore, based on consumer's experience in online and offline channel, they may form and update their brand images of a multichannel retailer (Kwon \& Lennon, 2009). Therefore, offline brand image is expected to lead to purchase offline, with online search playing a mediating role in this relationship. Thus, the following research question is posed:

RQ1a: To what extent does online search mediate the relationship between offline brand image and offline purchase?

According to Yang et al. (2012) the benefits of online channel lead to the use of online channel. This study expects that online search can lead to offline purchase due to consumer enjoyment of offline shopping.

Dennis et al. (2005) report that offline shopping enjoyment is considered as a motivation for brick-and-mortar shopping, as opposed to shopping on the Internet. The importance of enjoyment to modern physical store is clear (Hart et al., 2007). While the online channel is a useful channel to compare information about various products, offline shopping enjoyment may be more important to those high on this trait, and lead them to have lower tendency to make a purchase online. Thus, the following research question render as important: 
RQ1b: Is the mediating effect of online search in the relationship between offline brand image and offline purchase moderated by offline shopping enjoyment?

According to Kwon and Lennon (2009) a National Survey reports that online respondents would be less likely to shop from the retailer's offline store (40 percent) after a negative experience, their opinion of the retailer/brand was negatively affected ( 60 percent), and would not return to the site to search or purchase ( 80 percent).

The use of different channels to acquire information about and to buy a product may provide consumers with economic benefits (e.g., online price may be lower) and psychological benefits (feeling smart) (Dolen \&Verhagen, 2009). Dolen and Verhagen (2009) suggested that searching on the Internet may provide consumers with price information, allowing them to obtain a better price in a store. Therefore, online channels lead consumers to access data online to make shopping comparisons and evaluate prices without being pressured by salespeople.

Kwon and Lennon (2009) show that online brand image causes online consumer loyalty which can be a factor to move consumers to search online. Thus, the following research question is posed:

RQ2a: To what extent does online search mediate the relationship between online brand image and offline purchase?

However, the motivations for offline channel choice are mostly connected to experience in offline shopping by the offline shopping enjoyment. Thus, the following research questions render as important:

RQ2b: Is the mediating effect of online search in the relationship between online brand image and offline purchase moderated by offline shopping enjoyment?

\subsection{Service Quality: Offline and Online}

Perceived service quality involves the consumer's judgment about the extent of superiority or excellence of the product (Zeithaml, 1988). Different studies focus on online service quality which can be split into two categories: online retailing services and website design quality. Zeithaml et al. (2002) and Parasuraman, Zeithaml and Malhotra (2005) study that Internet service quality which is defined as the degree to which a web site facilitates effective and efficient purchasing.

According to Shine et al. (2013) the perceived quality of an online shopping influences satisfaction; and that satisfaction influences consumer online loyalty which can be lead to online search. Thus, the following research question is posed:

RQ3a: To what extent does online search mediate the relationship between online service quality and offline purchase?

While according to Yang et al. (2012) the benefits of online channel lead to purchase from online channel, based on a similar argument as above, this study expects that online search, as the benefit of online channel, can be lead to offline purchase due to consumer enjoyment of offline shopping. Thus, the following research question renders as important:

RQ3b: Is the mediating effect of online search in the relationship between online service quality and offline purchase moderated by offline shopping enjoyment?

Liu and Guo (2008) demonstrate that offline service quality can lead to offline loyalty by providing good customer service to consumers. Offline service quality is not available or reachable, consumers will perceive that companies are not intending to solve their problems or trying to hide something (Katawetawaraks et al., 2011), so lose their loyalty. It can be assumed, therefore, that the consumer will leave with a more favourable impression or positive image of the retail encounter or at least individual service encounter or individual store if employees display positive attitudes or sufficiently impress the consumer. Customer service quality can therefore be considered a dimension of the holistic physical store image in that it represents the 'augmented product' that supports the basic merchandising function of the shopping store (Sit et al., 2003). Chen (2008) suggests that consumer perceptions of service quality and satisfaction with the service have positive and significant effects on future intentions to purchase. Based on a similar argument to that advanced above, it is argued here that offline service quality can lead to offline loyalty, then online search. Consumers access information from online channel but they prefer to purchase offline. Thus, the following research question is posed:

RQ4a: To what extent does online search mediate the relationship between offline service quality and offline purchase?

While Yang et al. (2012) show that, the benefits of online channel such as online search lead to purchase from 
online channel, this study expects that online channel can be lead to offline purchase due to customer enjoyment of offline shopping. Thus, the following research questions render as important:

RQ4b: Is the mediating effect of online search in the relationship between offline service quality and offline purchase moderated by offline shopping enjoyment?

\subsection{Convenience: Offline and Online}

Convenience is acknowledged to be increasingly important to consumers (Berry et al., 2002). Convenience is defined in terms of saving time and effort, including physical and mental effort (Nicholas et al., 1978). In general, shopping convenience is one of the reasons that many shoppers enjoy shopping (Shin et al., 2013). Time-poor consumers require a lot of value from the limited hours available and may be willing to pay more money to enjoy their leisure time (Engel, Blackwell, \& Miniard, 1995; Akaah, et al., 1995). Retailers currently develop strategies to enable consumers to save time by making the shopping process less time consuming and more convenient (Berry et al., 2002). The efficiency of shopping has been recognized to be a key influencer of consumer behaviour in the offline context (Engel et al., 1995; Kerin et al., 1992).

Changing consumer lifestyles and lack of time may make it more difficult for consumers to search and shop at physical locations such as stores (Davies, 1995, Cheeseman \& Breddin, 1995). In addition, it would take a short time to search at the website and buyers could search from the website without much help (Shin et al., 2013). Therefore, online convenience can lead to search online. Thus, the following research question is posed:

RQ5a: To what extent does online search mediate the relationship between online convenience and offline purchase?

Moreover offline shopping enjoyment is found as a major driver that exerts a pull on shopper's visit to a physical store (Dawson et al., 1990; Koufaris et al., 2002). Thus, despite the previous empirical research in that convenience of the Internet impacts on consumers' willingness to buy online (Wang et al., 2005), this study expects that online search can be lead to offline purchase due to customer enjoyment of offline shopping. Thus, the following research question render as important:

RQ5b: Is the mediating effect of online search in the relationship between online convenience and offline purchase moderated by offline shopping enjoyment?

Convenience is defined in terms of saving time and effort, including physical and mental effort (Williams et al., 1978). In addition, accessibility of the store (location and hours of availability) has been included in some conceptualizations of offline convenience (Corby, 1994).

The implication of transaction inconvenience is converging nonmonetary cost (time and effort) and monetary cost before consumers experience any benefits (Berry et al., 2002). Thus, the following research question is posed:

RQ6a: To what extent does online search mediate the relationship between offline convenience and offline purchase?

It is argued that shopping enjoyment increased consumers' satisfaction with the store, amount of time spent in the store and spending levels (Forsythe \& Bailey, 1996). Those who enjoy shopping always look for the attractive décor in the stores as well as exciting shopping experience (Wong et al., 2012). It is argued that online channel is a good way to collect information and offline channel can attract consumers because of shopping enjoyment including window shopping and fun. Thus, the following research questions render as important:

RQ6b: Is the mediating effect of online search in the relationship between offline convenience and offline purchase moderated by offline shopping enjoyment?

\section{Methodology}

\subsection{Sample}

The sampling framework for the present research consisted of consumers who had recent shopping experience with the offline channel and search experience using the online channel of a retailer. Data collection was conducted via an online survey administered to a consumer panel in the USA. Retrospective sampling was adopted for the study which is characterized by allowing respondents to reflect on their recent shopping and purchase experiences with the online and offline channel in responding to the survey instrument. Respondents had to have made a purchase in the bricks and mortar outlet (i.e., retail store), as well as the online search of the same retailer in the last 6 months. In this sense, the data set is neither firm nor product category specific. The choice of retrospective experience sampling employing panel members is also consistent with previous retail 
studies (Kwon \& Lennon, 2009; Yang et al., 2012; Shin et al., 2013). The panel includes registered members. The invitation and link of survey was sent to 250 panel members via email. Out of 250 sent survey, 200 members agreed to participate. Out of 200 distributed surveys, 186 completed and useable surveys were received.

\subsection{Measures}

Each construct in this study was measured with multiple items, and all of these items were adopted from the extant literature by modifying the wording of the questions to fit the study context. Four of the constructs including online/offline service quality, online/offline convenience, and online/offline shopping enjoyment were assessed via multi-item measures using a 7-point Likert scale, with response choices ranging from one (Strongly disagree) to seven (Strongly agree). Online and offline brand image were assessed via multi-item measures using a 7-point Likert scale, i.e., Not at all (1) or very much (7). The survey also measured online/offline search and online/offline purchase variables. These are measured on a 7-point Likert scale, with (1) representing Not likely at all and (7) representing very likely on that measure. Five items on offline and online service quality were adapted from Yang et al. (2012) and measured the five components of perceived service quality: tangibles, reliability, responsiveness, assurance, and empathy. Offline convenience was measured with three items and online convenience was measured with four items adapted from Shin et al. (2013). Offline and online brand Image items are adopted from Aaker (1996) which measured the five components of online brand Image and seven components of Offline brand image. The remaining questions asked about offline and online enjoyment adapted from Kaufaris (2002) which measured three items. Offline and Online search adapted from Kau et al.(2003) which measured one item each and also, offline and online purchase which measured by one item adapted from Kau et al. (2003).

\section{Results}

\subsection{Profile of the Respondents}

Out of 186 completed surveys received, $46 \%$ are male and $53 \%$ are female. $55 \%$ of the respondents were between the ages of 15 and 61 years, with the mean age of 31 years old. Respondents are students $(23.9 \%)$, homemakers $(12.2 \%)$ and freelance $(20.6 \%)$ occupations, and predominately $29.4 \%$ of respondents are in bachelor degrees and .6\% is lower than high school diploma, and. $73.9 \%$ of respondents is with income less than $\$ 60,000$.

\subsection{Findings}

In this study convergent validity was assessed by Cronbach's alpha to evaluate the reliabilities of constructs (Carlson \& O'Cass, 2010). Cronbach's alpha can be described as a coefficient of reliability that measures how well a set of items measure a single uni-dimensional latent construct (i.e. inter-item consistency) and is estimated using the reliability analysis procedure in SPSS (Carlson \& O'Cass, 2010). As shown in the Appendix 1, the Cronbach's alpha coefficient for all constructs was acceptable, ranging from 0.73 to 0.92 .

A factor analysis with the principal component analysis with varimax was performed construct by construct. In particular, for online and offline convenience, the KMO measure of sampling adequacy was close to 1 and the Bartlett's Test of sphericity was significant, indicating that the sample size was sufficient for factor analysis. Also, all communalities were above 0.50 . The total variance explained extracted was $79 \%$, all items loaded on their respective constructs, with all factor loadings being above .50 .

For online and offline brand image, the KMO measure of sampling adequacy was close to 1 and the Bartlett's Test of sphericity was significant, indicating that the sample size was sufficient for factor analysis. Also, all communalities were above 0.50 . The total variance explained extracted was $77 \%$, all items loaded on their respective constructs, with all factor loadings being above .50 .

The online and offline service quality, the KMO measure of sampling adequacy was close to 1 and the Bartlett's Test of sphericity was significant, indicating that the sample size was sufficient for factor analysis. Also, all communalities were above 0.50 . The total variance explained extracted was $72 \%$, all items loaded on their respective constructs, with all factor loadings being above .50 .

The analysis indicates that all constructs associated with outer-measurement models exhibited convergent validity and discriminate validity (Appendix 1- Table I) presents the loadings and reliability scores for each construct within sample. Therefore, to conduct data analyses, the composite scale of each construct was used by averaging the construct's respective items.

\subsection{Test of Research Questions}

Research question 1a focuses on the indirect effect of offline brand image on offline purchase through online 
search. To test this effect, PROCESS macro (Model 4) developed by Hayes (2013) was used. In the mediation model, offline brand image was the independent variable, search online was the mediator, and purchase offline was the dependant variable.

Table 1. The indirect effect of offline brand image on offline purchase mediated by online search

\begin{tabular}{cccccccccc}
\hline IV & Mediator & DV & a path & b path & c path & c' path & a*b path & LLCI & ULCI \\
\hline $\begin{array}{c}\text { Offline } \\
\text { brand }\end{array}$ & $\begin{array}{c}\text { Online } \\
\text { image }\end{array}$ & search & $\begin{array}{c}\text { Offline } \\
\text { purchase }\end{array}$ & $.46^{* *}$ & $.24 * *$ & $.42^{* *}$ & $.42^{* *}$ & .11 & .02 \\
\hline
\end{tabular}

Notes:

a path $=$ the effect of IV (the independent variable) on $\mathrm{M}$ (the mediator)

$\mathrm{b}$ path $=$ the effect of $\mathrm{M}$ on DV (the dependent variable)

c path $=$ the total effect of IV on DV

c' path = the direct effect of IV on DV

$a * b$ path $=$ the indirect effect of IV on DV

LLCI and ULCI = Lower and upper level bootstrap confidence intervals for the indirect effect based on 5000 samples

*: p-value $<.05$

**: p-value $<.01$

Research question $1 \mathrm{~b}$ investigates the indirect effect of offline brand image on offline purchase through online search by offline shopping enjoyment as a moderator. To test this effect, PROCESS macro (Model 14) developed by Hayes (2013) was used. In the test, offline brand image was the independent variable, online search was the mediating variable, offline purchase was the dependent variable, and offline shopping enjoyment was the moderator. The results are shown in Table 2. As can be seen, the interaction effect of offline brand image and offline shopping enjoyment on offline purchase was not significant with a regression coefficient of $-.12(p<.10)$.

Also, the bootstrapping confidence interval for the moderating effect of offline shopping enjoyment in the mediating effect of online search in the relationship between offline brand image and offline purchase does not include the value of zero (LLCI $=-.24$, ULCI $=-.005$ ). Therefore, offline shopping enjoyment does not moderate the mediating effect of online search in the relationship between offline brand image and offline purchase. Therefore, in answering RQ1b, the mediating effect of online search in the relationship between offline brand image and offline purchase is not moderated by offline shopping enjoyment.

Table 2. The moderating effect of offline shopping enjoyment in the indirect effect of offline brand image on offline purchase mediated through online search

\begin{tabular}{|c|c|c|c|c|c|c|c|}
\hline IV & Mediator & DV & Moderator & $\begin{array}{l}\text { Interaction } \\
\text { Coefficient }\end{array}$ & P-value & LLCI & ULCI \\
\hline $\begin{array}{l}\text { offline } \\
\text { brand } \\
\text { image }\end{array}$ & $\begin{array}{l}\text { Online } \\
\text { Search }\end{array}$ & $\begin{array}{l}\text { Offline } \\
\text { Purchase }\end{array}$ & $\begin{array}{c}\text { Offline shopping } \\
\text { enjoyment }\end{array}$ & -.12 & .04 & -.15 & .00 \\
\hline
\end{tabular}

Research question 2a investigates the indirect effect of online brand image on offline purchase through online search. To test this effect the PROCESS macro (Model 4) developed by Hayes (2013) was used. In the mediation model, online brand image was the independent variable, search online was the mediator, and purchase offline was the dependant variable. The results are presented in Table 3. As can be seen, the main effect of online brand image on online search is significant with a regression coefficient of $.51(p<.01)$. The regression coefficient for the effect of online search on offline purchase is significant $(b=.27, p<.01)$. The total effect of online brand image on offline purchase is significant with a regression coefficient of $.27(\mathrm{p}>.01)$. The direct effect of online brand image on offline purchase is significant with a regression coefficient of $.27(\mathrm{p}>.01)$. The indirect effect of online brand image on offline purchase mediated by online search is significant with a regression coefficient of $.14(\mathrm{p}<.01)$. This is indicated by the bootstrapping confidence interval for this effect, which does not include 
the value of zero $(\mathrm{LLCI}=.01, \mathrm{ULCI}=.30)$, therefore, online search mediates the relationship between online brand image and offline purchase. Therefore, online search partially mediates the effect of online brand image on offline purchase as the indirect effect of online brand image on offline purchase is still significant. Therefore, in answering RQ2a, online search mediates the relationship between online brand image and offline purchase significantly.

Table 3. The indirect effect of online brand image on offline purchase mediated by online search

\begin{tabular}{cccccccccc}
\hline IV & Mediator & DV & a path & b path & c path & c' path & $\mathrm{a}^{*}$ b path & LLCI & ULCI \\
\hline $\begin{array}{c}\text { Online } \\
\text { brand } \\
\text { image }\end{array}$ & $\begin{array}{c}\text { Online } \\
\text { search }\end{array}$ & $\begin{array}{c}\text { Offline } \\
\text { purchase }\end{array}$ & $.51^{* *}$ & $.27^{* *}$ & .27 & .27 & .14 & .01 & .30 \\
\hline
\end{tabular}

Notes:

a path $=$ the effect of IV (the independent variable) on M (the mediator)

$\mathrm{b}$ path $=$ the effect of $\mathrm{M}$ on DV (the dependent variable)

c path $=$ the total effect of IV on DV

c' path $=$ the direct effect of IV on DV

$a * b$ path $=$ the indirect effect of IV on DV

LLCI and ULCI = Lower and upper level bootstrap confidence intervals for the indirect effect based on 5000 samples

$*$ : p-value $<.05$

**: p-value $<.01$

Research question $2 \mathrm{~b}$ examines the indirect effect of online brand image on offline purchase through online search by offline shopping enjoyment as a moderator. To test this effect, PROCESS macro (Model 14) developed by Hayes (2013) was used. In the test, online brand image was the independent variable, online search was the mediating variable, offline purchase was the dependent variable, and offline shopping enjoyment was the moderator. The results are shown in Table 4. As can be seen, the interaction effect of online brand image and offline shopping enjoyment on offline purchase was not significant with a regression coefficient of $-.11(\mathrm{p}<.10)$.

Also, the bootstrapping confidence interval for the moderating effect of offline shopping enjoyment in the mediating effect of online search in the relationship between online brand image and offline purchase does not includes the value of zero (LLCI $=-.23$, ULCI $=.00$ ). Therefore, offline shopping enjoyment does not moderate the mediating effect of online search in the relationship between online brand image and offline purchase.

Therefore, in answering RQ2b, the mediating effect of online search in the relationship between online brand image and offline purchase is not moderated by offline shopping enjoyment.

Table 4. The moderating effect of offline shopping enjoyment in the indirect effect of online brand image on offline purchase mediated through online search

\begin{tabular}{cccccccc}
\hline IV & Mediator & DV & Moderator & $\begin{array}{c}\text { Interaction } \\
\text { Coefficient }\end{array}$ & P-value & LLCI & ULCI \\
\hline $\begin{array}{c}\text { online brand } \\
\text { image }\end{array}$ & $\begin{array}{c}\text { Online } \\
\text { Search }\end{array}$ & $\begin{array}{c}\text { Offline } \\
\text { Purchase }\end{array}$ & $\begin{array}{c}\text { Offline shopping } \\
\text { enjoyment }\end{array}$ & -.11 & .06 & -.15 & .01 \\
\hline
\end{tabular}

Research question 3a investigates the indirect effect of online service quality on offline purchase through online search. To test this effect the PROCESS macro (Model 4) developed by Hayes (2013) was used. In the mediation model, online service quality was the independent variable, search online was the mediator, and purchase offline was the dependant variable. The results are presented in Table 5. As can be seen, the main effect of online service quality on online search is significant with a regression coefficient of $.50(\mathrm{p}<.01)$. The regression coefficient for the effect of online search on offline purchase is significant $(b=.27, p<.01)$. The total effect of online service quality on offline purchase is significant with a regression coefficient of $.22(p>.01)$. The direct effect of online service quality on offline purchase is significant with a regression coefficient of $.22(p>.01)$. The regression 
coefficient for the indirect effect of online service quality on offline purchase mediated by online search is significant $(\mathrm{b}=.13, \mathrm{p}<.01)$. This is indicated by the bootstrapping confidence interval for this effect, which include the value of zero $(\mathrm{LLCI}=.00, \mathrm{ULCI}=.33$ ), therefore, online search mediates the relationship between online service quality and offline purchase. Therefore, online search partially mediates the effect of online service quality on offline purchase as the indirect effect of online service quality on offline purchase is still significant. Therefore, in answering RQ3a, online search mediates the relationship between online service quality and offline purchase significantly.

Table 5. The indirect effect of online service quality on offline purchase mediated by online search

\begin{tabular}{cccccccccc}
\hline IV & Mediator & DV & a path & b path & c path & c' path & a*b path & LLCI & ULCI \\
\hline $\begin{array}{l}\text { Online } \\
\text { service } \\
\text { quality }\end{array}$ & $\begin{array}{c}\text { Online } \\
\text { search }\end{array}$ & $\begin{array}{c}\text { Offline } \\
\text { purchase }\end{array}$ & $.50^{* *}$ & $.27^{* *}$ & .22 & .22 & .13 & .00 & .33 \\
\hline
\end{tabular}

Notes:

a path $=$ the effect of IV (the independent variable) on $\mathrm{M}$ (the mediator)

$\mathrm{b}$ path $=$ the effect of M on DV (the dependent variable)

$\mathrm{c}$ path $=$ the total effect of IV on DV

c' path = the direct effect of IV on DV

$a * b$ path $=$ the indirect effect of IV on DV

LLCI and ULCI = Lower and upper level bootstrap confidence intervals for the indirect effect based on 5000 samples

$*$ : p-value $<.05$

$* *$ : p-value $<.01$

Research question $3 b$ examines the indirect effect of online service quality on offline purchase through online search by offline shopping enjoyment as a moderator. To test this effect, PROCESS macro (Model 14) developed by Hayes (2013) was used. In the test, online service quality was the independent variable, online search was the mediating variable, offline purchase was the dependent variable, and offline shopping enjoyment was the moderator. The results are shown in Table 6. As can be seen, the interaction effect of online service quality and offline shopping enjoyment on offline purchase was not significant with a regression coefficient of $-.13(p<.10)$.

Also, the bootstrapping confidence interval for the moderating effect of offline shopping enjoyment in the mediating effect of online search in the relationship between online service quality and offline purchase does not includes the value of zero (LLCI $=-.25$, ULCI $=-.008$ ). Therefore, offline shopping enjoyment moderates the mediating effect of online search in the relationship between online service quality and offline purchase. Therefore, in answering RQ3b, the mediating effect of online search in the relationship between online service quality and offline purchase is not moderated by offline shopping enjoyment.

Table 6. The moderating effect of offline shopping enjoyment in the indirect effect of online service quality on offline purchase mediated through online search

\begin{tabular}{cccccccc}
\hline IV & Mediator & DV & Moderator & $\begin{array}{c}\text { Interaction } \\
\text { Coefficient }\end{array}$ & P-value & LLCI & ULCI \\
\hline $\begin{array}{c}\text { Online service } \\
\text { quality }\end{array}$ & $\begin{array}{c}\text { Online } \\
\text { Search }\end{array}$ & $\begin{array}{c}\text { Offline } \\
\text { Purchase }\end{array}$ & $\begin{array}{c}\text { Offline shopping } \\
\text { enjoyment }\end{array}$ & -.13 & .03 & -.16 & -.001 \\
\hline
\end{tabular}

Research question 4a investigates the indirect effect of offline service quality on offline purchase through online search. To test this effect the PROCESS macro (Model 4) developed by Hayes (2013) was used. In the mediation model, offline service quality was the independent variable, search online was the mediator, and purchase offline was the dependant variable. The results are presented in Table 7. As can be seen, the main effect of offline service quality on online search is significant with a regression coefficient of $.65(\mathrm{p}<.01)$.

The effect of online search on offline purchase is significant with a regression coefficient of .26 (p > .01). The 
total effect of offline service quality on offline purchase is significant with a regression coefficient of .23 $(p>.01)$. The direct effect of offline service quality on offline purchase is significant with a regression coefficient of $.23(\mathrm{p}>.01)$. The indirect effect of offline service quality on offline purchase mediated by online search was significant with a regression coefficient of $.17(\mathrm{p}<.01)$. This is indicated by the bootstrapping confidence interval for this effect, which does not include the value of zero (LLCI $=-.006, \mathrm{ULCI}=.37$ ), therefore, online search does not mediates the relationship between offline service quality and offline purchase. Thus, in answering RQ4a, online search not mediates the relationship between offline service quality and offline purchase.

Table 7. The indirect effect of offline service quality on offline purchase mediated by online search

\begin{tabular}{cccccccccc}
\hline IV & Mediator & DV & a path & b path & c path & c' path & a*b path & LLCI & ULCI \\
\hline $\begin{array}{l}\text { Offline } \\
\text { service } \\
\text { quality }\end{array}$ & $\begin{array}{c}\text { Online } \\
\text { search }\end{array}$ & $\begin{array}{c}\text { Offline } \\
\text { purchase }\end{array}$ & $.65^{* *}$ & .26 & .23 & .23 & .17 & -.006 & .37 \\
\hline
\end{tabular}

Notes:

a path $=$ the effect of IV (the independent variable) on M (the mediator)

$\mathrm{b}$ path $=$ the effect of $\mathrm{M}$ on DV (the dependent variable)

c path $=$ the total effect of IV on DV

c' path $=$ the direct effect of IV on DV

$a * b$ path $=$ the indirect effect of IV on DV

LLCI and ULCI = Lower and upper level bootstrap confidence intervals for the indirect effect based on 5000 samples

*: p-value $<.05$

$* *$ : p-value $<.01$

Research question $4 \mathrm{~b}$ examines the indirect effect of offline service quality on offline purchase through online search by offline shopping enjoyment as a moderator. To test RQ4b, PROCESS macro (Model 14) developed by Hayes (2013) was used. In the test, offline service quality was the independent variable, online search was the mediating variable, offline purchase was the dependent variable, and offline shopping enjoyment was the moderator. The results are shown in Table 8. As can be seen, the interaction effect of offline service quality and offline shopping enjoyment on offline purchase was not significant with a regression coefficient of $-.11(\mathrm{p}<.10)$.

Also, the bootstrapping confidence interval for the moderating effect of offline shopping enjoyment in the mediating effect of online search in the relationship between offline service quality and offline purchase does not includes the value of zero (LLCI $=-.24, \mathrm{ULCI}=.00$ ). Therefore, offline shopping enjoyment does not moderate the mediating effect of online search in the relationship between offline service quality and offline purchase.

Therefore, in answering RQ4b, the mediating effect of online search in the relationship between offline service quality and offline purchase is not moderated by offline shopping enjoyment.

Table 8. The moderating effect of offline shopping enjoyment in the indirect effect of offline service quality on offline purchase mediated through online search

\begin{tabular}{cccccccc}
\hline IV & Mediator & DV & Moderator & $\begin{array}{c}\text { Interaction } \\
\text { Coefficient }\end{array}$ & P-value & LLCI & ULCI \\
\hline $\begin{array}{c}\text { offline service } \\
\text { quality }\end{array}$ & $\begin{array}{c}\text { Online } \\
\text { Search }\end{array}$ & $\begin{array}{c}\text { Offline } \\
\text { Purchase }\end{array}$ & $\begin{array}{c}\text { Offline shopping } \\
\text { enjoyment }\end{array}$ & -.11 & .06 & -.18 & .01 \\
\hline
\end{tabular}

Research question 5a investigates the indirect effect of online convenience on offline purchase through online search. To test this effect the PROCESS macro (Model 4) developed by Hayes (2013) was used. In the mediation model, online convenience was the independent variable, search online was the mediator, and purchase offline was the dependant variable. The results are presented in Table 9. As can be seen, the main effect of online convenience on online search is significant with a regression coefficient of $.65(p<.01)$. The effect of online 
search on offline purchase is significant with a regression coefficient of $.26(p>.01)$. The total effect of online convenience on offline purchase is significant with a regression coefficient of $.18(\mathrm{p}>.01)$. The direct effect of online convenience on offline purchase is significant with a regression coefficient of $.18(\mathrm{p}>.01)$. The indirect effect of online convenience on offline purchase mediated by online search was significant with a regression coefficient of $.17(\mathrm{p}<.01)$. This is indicated by the bootstrapping confidence interval for this effect, which include the value of zero (LLCI $=.00, \mathrm{ULCI}=.40)$, therefore, online search mediates the relationship between online convenience and offline purchase. Therefore, online search partially mediates the effect of online convenience on offline purchase as the indirect effect of online convenience on offline purchase is still significant. Therefore, in answering RQ5a, online search mediates the relationship between online convenience and offline purchase.

Table 9. The indirect effect of online convenience on offline purchase mediated by online search

\begin{tabular}{cccccccccc}
\hline IV & Mediator & DV & a path & b path & c path & c' path & a*b path & LLCI & ULCI \\
\hline $\begin{array}{c}\text { Online } \\
\text { convenience }\end{array}$ & $\begin{array}{c}\text { Online } \\
\text { search }\end{array}$ & $\begin{array}{c}\text { Offline } \\
\text { purchase }\end{array}$ & $.65^{* *}$ & .26 & .18 & .18 & .17 & .00 & .40 \\
\hline
\end{tabular}

Notes:

a path = the effect of IV (the independent variable) on M (the mediator)

$\mathrm{b}$ path $=$ the effect of $\mathrm{M}$ on DV (the dependent variable)

c path $=$ the total effect of IV on DV

c' path = the direct effect of IV on DV

$a^{*} b$ path $=$ the indirect effect of IV on DV

LLCI and ULCI = Lower and upper level bootstrap confidence intervals for the indirect effect based on 5000 samples

*: p-value $<.05$

$* *$ : p-value $<.01$

Research question $5 b$ examines the indirect effect of online convenience on offline purchase through online search by offline shopping enjoyment as a moderator. To test RQ5b, PROCESS macro (Model 14) developed by Hayes (2013) was used. In the test, online convenience was the independent variable, online search was the mediating variable, offline purchase was the dependent variable, and offline shopping enjoyment was the moderator. The results are shown in Table 10. As can be seen, the interaction effect of online convenience and offline shopping enjoyment on offline purchase was not significant with a regression coefficient of $-.11(\mathrm{p}<.10)$.

Also, the bootstrapping confidence interval for the moderating effect of offline shopping enjoyment in the mediating effect of online search in the relationship between online convenience and offline purchase does not includes the value of zero (LLCI $=-.23, \mathrm{ULCI}=.00$ ). Therefore, offline shopping enjoyment does not moderate the mediating effect of online search in the relationship between online convenience and offline purchase.

Therefore, in answering RQ5b, the mediating effect of online search in the relationship between online convenience and offline purchase is not moderated by offline shopping enjoyment.

Table 10. The moderating effect of offline shopping enjoyment in the indirect effect of online convenience on offline purchase mediated through online search

\begin{tabular}{cccccccc}
\hline IV & Mediator & DV & Moderator & $\begin{array}{c}\text { Interaction } \\
\text { Coefficient }\end{array}$ & P-value & LLCI & ULCI \\
\hline $\begin{array}{c}\text { Online } \\
\text { convenience }\end{array}$ & $\begin{array}{c}\text { Online } \\
\text { Search }\end{array}$ & $\begin{array}{c}\text { Offline } \\
\text { Purchase }\end{array}$ & $\begin{array}{c}\text { Offline shopping } \\
\text { enjoyment }\end{array}$ & -.11 & .06 & -.16 & .02 \\
\hline
\end{tabular}

Research question 6a investigates the indirect effect of offline convenience on offline purchase through online search. To test this effect the PROCESS macro (Model 4) developed by Hayes (2013) was used. In the mediation model, offline convenience was the independent variable, search online was the mediator, and purchase offline was the dependant variable. The results are presented in Table 11. As can be seen, the main effect of offline 
convenience on online search is significant with a regression coefficient of $.48(\mathrm{p}<.01)$. The effect of online search on offline purchase is significant with a regression coefficient of .23 $(p>.01)$. The total effect of offline convenience on offline purchase is significant with $b=.32(p<.01)$. The direct effect of offline convenience on offline purchase is significant with a regression coefficient of $.32(\mathrm{p}<.01)$. The indirect effect of offline convenience on offline purchase mediated by online search was significant with a regression coefficient of .11(p $<.01)$. This is indicated by the bootstrapping confidence interval for this effect, which does not include the value of zero (LLCI $=-.005$, ULCI $=.27$ ), therefore, online search does not mediate the relationship between offline convenience and offline purchase. Therefore, in answering RQ6a, online search does not mediate the relationship between offline convenience and offline purchase significantly.

Table 11. The indirect effect of offline convenience on offline purchase mediated by online search

\begin{tabular}{cccccccccc}
\hline IV & Mediator & DV & a path & b path & c path & c' path & a*b path & LLCI & ULCI \\
\hline $\begin{array}{c}\text { Offline } \\
\text { convenience }\end{array}$ & $\begin{array}{c}\text { Online } \\
\text { search }\end{array}$ & $\begin{array}{c}\text { Offline } \\
\text { purchase }\end{array}$ & $.48^{*}$ & .23 & $.32^{* *}$ & $.32^{* *}$ & .11 & -.005 & .27 \\
\hline
\end{tabular}

Notes:

a path $=$ the effect of IV (the independent variable) on $\mathrm{M}$ (the mediator)

$\mathrm{b}$ path $=$ the effect of M on DV (the dependent variable)

c path $=$ the total effect of IV on DV

c' path $=$ the direct effect of IV on DV

$a * b$ path $=$ the indirect effect of IV on DV

LLCI and ULCI = Lower and upper level bootstrap confidence intervals for the indirect effect based on 5000 samples

$*$ : p-value $<.05$

$* *$ : p-value $<.01$

Research question $6 \mathrm{~b}$ examines the indirect effect of offline convenience on offline purchase through online search by offline shopping enjoyment as a moderator. To test RQ6b, PROCESS macro (Model 14) developed by Hayes (2013) was used. In the test, offline convenience was the independent variable, online search was the mediating variable, offline purchase was the dependent variable, and offline shopping enjoyment was the moderator. The results are shown in Table 12. As can be seen, the interaction effect of offline convenience and offline shopping enjoyment on offline purchase was not significant with $b=-.11(p<.10)$.

Also, the bootstrapping confidence interval for the moderating effect of offline shopping enjoyment in the mediating effect of online search in the relationship between offline convenience and offline purchase does not includes the value of zero $(\mathrm{LLCI}=-.23, \mathrm{ULCI}=.00$ ). Therefore, offline shopping enjoyment does not moderate the mediating effect of online search in the relationship between offline convenience and offline purchase. Thus, RQ6b addressing the mediating effect of online search in the relationship between offline convenience and offline purchase is not moderated by offline shopping enjoyment.

Table 12. The moderating effect of offline shopping enjoyment in the indirect effect of offline convenience on offline purchase mediated through online search

\begin{tabular}{cccccccc}
\hline IV & Mediator & DV & Moderator & $\begin{array}{c}\text { Interaction } \\
\text { Coefficient }\end{array}$ & P-value & LLCI & ULCI \\
\hline $\begin{array}{c}\text { Offline } \\
\text { convenience }\end{array}$ & $\begin{array}{c}\text { Online } \\
\text { Search }\end{array}$ & $\begin{array}{c}\text { Offline } \\
\text { Purchase }\end{array}$ & $\begin{array}{c}\text { Offline shopping } \\
\text { enjoyment }\end{array}$ & -.11 & .05 & -.14 & .01 \\
\hline
\end{tabular}

\section{Discussion and Conclusion}

In this study it was aimed to investigate the factors affecting search online and purchase offline. This research includes 5 constructs of brand image, service quality, convenience, search online and purchase offline. And also, offline shopping enjoyment plays role as a moderator on the relationship between search online and purchase offline. 
According to the results, it was determined all research question are not significant and were not effective on search online and purchase offline; however, brand image on online and offline channel have a significant effect on attraction of consumers to search online and purchase offline. This study finds that consumer perception and satisfaction with service, brand image, and convenience have positive and significant effects on future intentions to search online and purchase offline.

Overall, the findings provide significant insights concerning the roles of brand image, service quality, and convenience on consumers' search online search and offline purchase decisions and the interplay of this effect with offline shopping enjoyment. The results of this study show that brand image in offline and online channel influences a consumer's intention to search online which motivates the consumer's offline purchase intention. Based on the empirical evidence, this study finds that brand image has the strongest direct effect on search online compared to service quality and convenience in online and offline channel. A positive image of search online can lead to purchase offline. Results showed that offline shopping enjoyment does not interact with search online to influence consumers to purchase offline and does not moderate the mediating effect of online search in the relationship between offline/online brand image and offline purchase. No relationships found between offline service quality and offline convenience with search online. Moreover, there is a significant positive relationship among search online and purchase offline which supported in the proposed research model. Offline shopping enjoyment does not affect in the relationship between online and offline service quality, online and offline brand image with search online and purchase offline.

\section{Implications}

\subsection{Theoretical Contributions}

This paper extends previous research in the following ways. First, this study is the first to investigate the effect of brand image, service quality, and convenience on search online and purchase offline. Second, this paper demonstrated that how search online can effect on the relationship of brand image, service quality, and convenience with offline purchase. Third, unlike previous studies that regard enjoyment as a consistent and strong predictor of attitude toward online and offline shopping (Childers et al., 2001), this study showed offline shopping enjoyment does not play a key role for the effect of service quality and convenience on attracting consumers to physical stores except in offline service quality.

\subsection{Managerial Implication}

Marketing practitioners require frameworks and models that enable them to better understand online and offline consumer shopping behavior (Carlson \& O'Cass, 2010). Thus, the model in this study offers practitioners a clear picture and a useful tool to better understand the relationship between brand image, service quality, and convenience with search online and purchase offline, and how these relationships may be influenced by shopping enjoyment as a personality characteristic.

The findings of this study show that online and offline brand image not only lead to more search online, but also increase offline purchase. Consequently, managers increasingly face the need to understand the ways their brands are perceived by their consumers so that marketing activities can be focused on brand and creating a specific name and personality dimension, to be attached to a strong brand. Also, retailers could better invest in communications across various channels aiming to bring more consumers to the physical store.

\section{Limitations and Future Research Directions}

This study is not without limitation. First, the sample of our study is restricted to consumer evaluations from a specific website through online survey. As such, caution is warranted in attempting to generalize these findings via online and offline surveys. Additional research could explore and compare the key constructs found in the framework with consumer evaluations across a variety of channels.

Second, investigating on a scaled geographical distribution through online survey, the researchers could not have full control of informants' biases while they were answering the questionnaire. Therefore, the results found in this study cannot fully reflect consumers' opinions on online and offline shopping.

Finally, the empirical relationships between online and offline brand image, online and offline service quality, offline and online convenience, with search online and purchase offline reported in this study are tentative in the sense that they are based on cross-sectional data. This is an important consideration given the dynamic nature of Internet technology and its continued development (O'Cass \& Carlson, 2010). Thus, longitudinal research should be considered to further understand changes during an extended period of consumption episodes by consumers. 


\section{References}

Akaah, I., Korgaonkar, P., \& Daulatram, L. (1995). Direct Marketing Attitudes. Journal of Business Research, 34(3), 211-219. http://dx.doi.org/10.1016/0148-2963(94)00119-Y

Babin, B., \& William, R. D. (1996). Good and Bad Shopping Vibes: Spending and Patronage Satisfaction', Journal of Business Research, 35(3), 201-206. http://dx.doi.org/10.1016/0148-2963(95)00125-5

Carlson, J., \& O'Cass, A. (2010). Exploring the relationships between e-service quality, satisfaction, attitudes and behaviours in content-driven e-service web sites', Journal of Services Marketing, 24(2), 112-127. http://dx.doi.org/10.1108/08876041011031091

Cronin, J., Brady, M. K., \& Hult, G. (2000). Assessing the effects of quality, value, and customer satisfaction on consumer behavioural intentions in service encounters. Journal of Retailing, 76(2), 193-218. http://dx.doi.org/10.1016/S0022-4359(00)00028-2

Davies, G. (1995). Bringing Stores to Shoppers - Not Shoppers to Stores', International Journal of Retail and Distribution Management, 23(1), 18-23. http://dx.doi.org/10.1108/09590559510078089

Engel, J., Blackwell, D., \& Miniard, P. (1995). Consumer Behavior: International Edition. Orlando: Dryden Press.

Forsythe, S. M., \& Bailey, A. (1996). Shopping enjoyment, perceived time poverty and time spent shopping. Journal of Clothing and Textiles Research, 14, 185-191. http://dx.doi.org/10.1177/0887302X9601400303

Karimi Takalo, T., Naser Sadr Abadi, A. R., Vesal, S. M., Mirzaei, A., \& Nawaser, K. (2013). Fuzzy Failure Analysis: A new approach to service quality analysis in higher education institutions. International Educational Studies, 6(9).

Kau, K., Tang, Y., \& Ghose, S. (2003). Typology of online shoppers. Journal of Consumer Marketing, 20(2), 139-156. http://dx.doi.org/10.1108/07363760310464604

Keller, K. (1993). Conceptualizing, Measuring, and Managing Customer-Based Brand Equity', Journal of Marketing, 57(1), 1-22. http://dx.doi.org/ 10.2307/1252054

Li, H, Kuo, C. H., \& Russell, M. (1999). The Impact of Perceived Channel Utilities, Shopping Orientations, and Demographics on the Consumer's Online Buying Behavior. Journal of Computer-Mediated Communication, 5(2). http://dx.doi.org/10.1111/j.1083-6101.1999.tb00336.x

Parasuraman, A., Zeithaml, V., \& Berry, L. (1988). SERVQUAL: A Multiple-Item Scale for Measuring Consumer Perceptions of Service Quality. Journal of Retailing, 64(1), 12-40. http://dx.doi.org/10.1177/1094670504271156

Pauwels, K., Leeflang, P., Teerling, M., \& Huizingh, K. (2011). Does Online Information Drive Offline Revenues? Only for Specific Products and Consumers Segments!' Journal of Retailing, 87(1), 1-17. http://dx.doi.org/10.1016/j.jretai.2010.10.001

Peterson, A., Balasubramanian, S., \& Bronnenberg, B. (1997). Exploring the implications of the internet for consumer marketing', Journal of the Academy of Marketing Science, 25(4), 329-346. http://dx.doi.org/10.1177/0092070397254005

Shin, J., Chung, K., Sin Oh, J., \& Won Lee, C. (2013). The effect of site quality on repurchase intention in Internet shopping through mediating variables: The case of university students in South Korea. International Journal of Information Management, 33, 453-463. http://dx.doi.org/10.1016/j.ijinfomgt.2013.02.003

Verhagen, T., \& Dolen, W. (2009). Online purchase intentions: A multi- channel store image perspective. Information\& Management, 46, 77-82. http://dx.doi.org/10.1016/j.im.2008.12.001

Verhoef, P., Neslin, S., \& Vroomen, B. (2007). Multi- Channel Customer Management: Understanding the Research Shopper Phenomenon. International Journal of Research in Marketing, 24(2), 129-48. http://dx.doi.org/10.1016/j.jiresmar.2006.11.002

Wong, Y., Osman, S., Jamaluddin, A., \& ChanYin-Fah, B. (2012). Shopping motives, store attributes and shopping enjoyment among Malaysian youth. Journal of Retailing and Consumer Services, 19, 240-248. http://dx.doi.org/10.1016/j.jretconser.2012.01.005

Zeithaml, V. (1988). Consumer Perceptions of Price, Quality and Value: A Means-End Model and Synthesis of Evidence. Journal of Marketing, 52, 2-22. http://dx.doi.org/10.2307/1251446 
Zeithaml, V., Parasuraman,A., \& Malhotra, A. (2002). Service Quality Delivery Through Web Sites: A Critical Review of Extant Knowledge. Journal of the Academy of Marketing Science, 30(4), 362-375. http://dx.doi.org/ 10.1177/009207002236911

\section{Copyrights}

Copyright for this article is retained by the author(s), with first publication rights granted to the journal.

This is an open-access article distributed under the terms and conditions of the Creative Commons Attribution license (http://creativecommons.org/licenses/by/4.0/). 